\title{
Towards the Transatlantic Trade and Investment Partnership (TTIP) between the European Union and United States
}

\begin{abstract}
In this research work, the author focuses on the analysis of the activity towards the Transatlantic Trade and Investment Partnership (TTIP) between the European Union and United States. It has been emphasized that the talks will reduce regulatory barriers. New agreements to remove trade barriers aim at reducing dead-weight costs and at increasing net social gains from international trade. The article examines the impact of free trade agreements like TTIP and, in particular, investor-state dispute resolution mechanisms in reducing the power of national governments to regulate and eliminate market inequality. The article offers examples of successful regulatory cooperation efforts in the hope that it will shed light on possible approaches to addressing regulatory divergences. Ideally, the best way to address problems arising from regulatory divergence would be on a multilateral basis, while taking into account the relations of the EU and the US with other countries. The main aim of the article is the presentation of the challenges for TTIP negotiations. The particular objective of the research task is the regulatory trade barriers in US-EU foreign trade policy, the nature and the promoters of TTIP, the interrelationship between regulatory standards and international cooperation in TTIP. The general theoretical approach will be of broad interest to economists interested in international questions, especially transatlantic cooperation, as well as to political scientists. The main methods applied in this research were the institutional method, comparative method, documentation method and statistical methods. Additionally, the methods of deductive and inductive forecasting were applied.
\end{abstract}

Key words: TTIP, regulatory barriers, international cooperation

\section{Introduction ${ }^{1}$}

$\mathbf{T}$ he United States of America (USA) and European Union (EU) combined, account for over $45 \%$ of nominal global GDP, and for $38 \%$ in terms of purchasing power parity. Foreign direct investment is intense between the two regions, and more than a third of the trade consists of intra-company trade, between subsidiaries of companies established both in the EU and in the United States (US).

The US and the EU are heavily invested in each other's market, with nearly $\$ 3.7$ trillion in two-way foreign direct investment at year-end 2011. Meanwhile, US-EU trade in goods and services totals about $\$ 1$ trillion annually. However, trade growth has been sluggish in recent years because of the effects of the 2008-09 financial crisis and competing subsidy and regulatory policies that impede commercial activity. A new trade accord would remove impediments to bilateral trade and investment. While it would not be a magic potion for prosperity, such reforms would improve the climate for investment and job creation, and provide a modest boost to economic growth, since removing even

${ }^{1}$ Paper prepared under Grant OPUS, National Centre of Science - NCS, No. UMO - 2013/11/B/ HS5/03572. 
relatively low barriers across a large volume of bilateral trade can have a significant impact.

New agreements to remove trade barriers aim at reducing dead-weight costs and at increasing net social gains from international trade. The World Trade Organization (WTO) was established with the mandate to lower trade barriers among its 159 member countries through rounds of trade negotiations. The WTO's "most-favored nation" principle states that preferential treatment of one country must be extended to all other members of the WTO. However, exceptions to this principle are frequent, due to the complexity of multilateral negotiations. There are hundreds of regional free trade agreements, sometimes called preferential trade agreements, as a reminder that third countries are excluded from the free trade gains.

The project for the trade agreement between the US and the EU, initially known as the Transatlantic Free Trade Area and later the Transatlantic Trade and Investment Partnership began with the 1995 Madrid Agreement on a Transatlantic Agenda, followed by various resolutions and negotiations between the US and the EU. In a recent report, the EU-US "high level working group on jobs and growth" (HLWG, 2013) analyzed a range of options far beyond simple tariff removals, including elimination of non-tariff barriers to trade in goods, services and investment, enhanced compatibility of regulations and standards and improved cooperation to achieve shared economic goals.

On July 8, 2013, the United States and the European Union launched negotiations on the Transatlantic Trade and Investment Partnership (TTIP). The negotiators aim to deepen what is already the world's largest commercial relationship, thereby "promoting greater growth and supporting more jobs," and to look beyond this particular accord "to contribute to the development of global rules that can strengthen the multilateral trading system." Beyond the important news that the world's two largest economies would be negotiating to liberalize trade, there was also a significant development in terms of the substance of the proposed talks. While past trade negotiations have dealt with domestic regulations as trade barriers in only narrow and limited ways, these talks would make reducing regulatory barriers a signature issue.

Traditional trade barriers, such as tariffs, are relatively low between the two economies, and regulatory barriers are an area that offers great potential economic gain. One widely cited 2009 study suggests some substantial benefits from addressing 'non-tariff measures', including regulatory divergence issues, within the context of US-EU trade. After noting that the 'total elimination' of such barriers would amount to a 2.5-3.0\% increase in GDP, the study then tried to identify those barriers that are 'actionable', that is, ones that could realistically be eliminated. Doing so, the report said, would boost EU GDP by $0.7 \%$ per year, leading to an annual potential gain of $\$ 158$ billion in 2008; and it would boost US GDP by $0.3 \%$, or $\$ 53$ billion per year.

Different regulations across countries in the same policy area raise costs for businesses and consumers, often without justification. Addressing these differences provides clear gains for efficiency, and benefits for all. Some of the more challenging regulatory issues, where there are strong policy disagreements between the US and EU, may need to be taken off the table. Furthermore, it is unlikely there will be success with broader regulatory reform efforts. Domestic efforts to achieve such reforms have had some success, but a global regime governing domestic regulations would be difficult to achieve 
and might not be desirable. Negotiators should go after the low-hanging fruit, and be responsive to the needs of industry and consumers by focusing their attention on areas where they can have the greatest impact (Lester, Barbee, 2013).

Currently, issues related to regulatory trade barriers are addressed in a number of fora, including the World Trade Organization (WTO) and the ongoing Trans-Pacific Partnership (TPP) negotiations. Nonetheless, because of the emphasis being placed on this issue in the TTIP, this may be the best forum to push the issue forward. If done right, TTIP could serve as a starting point for broader engagement on reducing the costly burden of regulatory divergence on international trade (Lester, Barbee, 2013). It must be stressed that the ideal route for the reduction of regulatory divergence would be through a multilateral effort involving various actors from both government agencies and the private sector.

\section{Materials and Methods}

The article sets out in general terms the importance of regulatory trade barriers, focusing on US-EU trade. It attempts to make the issues more concrete by discussing a number of real world examples of such barriers. It then talks about how international regulatory cooperation can address these issues in the abstract, before considering previous efforts undertaken in trade agreements. The article offers examples of successful regulatory cooperation efforts in the hope that this will shed light on possible approaches to addressing regulatory divergences. The article suggests that such an approach may be the best for TTIP, and could eventually be multilateralized. Negotiations on TIPP are being observed by various countries. The general theoretical approach will be of broad interest to economists interested in international questions, especially transatlantic cooperation, as well as to political scientists. The main methods applied in this research were the institutional method, comparative method, documentation method and statistical method. Additionally, the methods of deductive and inductive forecasting were applied.

\section{Discussion}

\section{Regulatory trade barriers in US-EU foreign trade policy}

The idea of transatlantic regulatory cooperation has been around for many years. Previous attempts, on the whole, have been relatively ad hoc and piecemeal, focused more on fostering dialogue than actually solving regulatory discrepancies. The TransAtlantic Business Dialogue, established in 1995, brought together business interests on both sides of the Atlantic in the hopes of developing strong public-private partnerships to allow products certified in one place to be accepted by the other. It was founded to deal with a major problem identified by its members, namely that competitiveness is hampered on both sides by excessive regulation, and by differences between EU and 
US regulatory systems (Egan, 2003). The Trans-Atlantic Business Council, had some early success with mutual recognition agreements in areas such as telecommunications equipment, certain medical devices, and other limited product areas (Lester and Barbee, 2013). However, the efforts seem to have lost momentum in recent years. Other efforts, such as the US-EU High Level Regulatory Cooperation Forum, have also produced limited results of a substantive nature, though these have encouraged an ongoing dialogue of the issues.

At this stage, though, little information is available on what specific issues will be addressed, or how liberalization in this area will be accomplished in the context of TTIP. A brief explanation is included in the report of the US-EU High Level Working Group (HLWG), which was established in November 2011 by US and EU political leaders to identify options for strengthening US-EU trade and investment relationship - that provides a framework for the talks (Final Report, 2013). In addition to the agenda proposed by the HLWG, the negotiators have committed themselves to find new rules on issues of global concern, such as protection of intellectual property and treatment of products and services provided by state-owned enterprises (Ries, 2014).

First, the report suggests expanding the existing technical barriers to trade (TBT) (Agreement on Technical..., 1994) and sanitary and phytosanitary measures (SPS) (Agreement on the Application..., 1994) rules of the WTO, by creating 'TBT-plus' and 'SPSplus' chapters (Final Report, 2013). Part of this will involve substantive obligations, and part will involve new procedures. Through the substantive obligations, the parties will be bringing issues of regulatory protectionism into TTIP. Regulatory protectionism is an important concern (Watson, James, 2013), and putting constraints on protectionist domestic regulations is one of the core goals of international trade rules. It is not clear how existing WTO rules - either the TBT or SPS agreements, or even more general rules such as GATT or the GATS - are insufficient in this area. These rules draw a delicate balance between imposing international disciplines on trade measures and respecting national autonomy (Lester, Barbee, 2013).

It must be emphasized that during the period from October 15, 2012 to May 15, 2013 WTO Members submitted 858 regular Technical Barriers to Trade (TBT) notifications; $80 \%$ of these notifications were submitted by Developing-country Members, including CIS (Commonwealth of Independent States) Members, with 34 notifications, and LDC (Least Developed Countries) Members, with 40 notifications. The largest number of notifications received during this period came from the Kingdom of Saudi Arabia (118 notifications). Other significant notifying members were the United States (66), Israel (54), Kenya (46), China (43), and the European Union (40) (WT/TPR/OV/W/7, 2013).

With respect to the stated objectives indicated in the regular notifications submitted, the overwhelming majority (more than $80 \%$ ) related either to the protection of human health or safety (564) or to the protection of the environment (134). Other relevant stated objectives included consumer information and labeling (52), and prevention of deceptive practices and consumer protection (36) (WT/TPR/OV/W/7, 2013).

Specific trade concerns (STCs) with respect to TBT measures taken by members can be raised at any of the three regular meetings of the TBT Committee each year; 21 new STCs were raised during the two Committee meetings that fell during the reviewed period (the November 2012 and March 2013 meetings) (Chart 1). 


\section{Chart 1. Issues raised in new TBT specific concerns*}

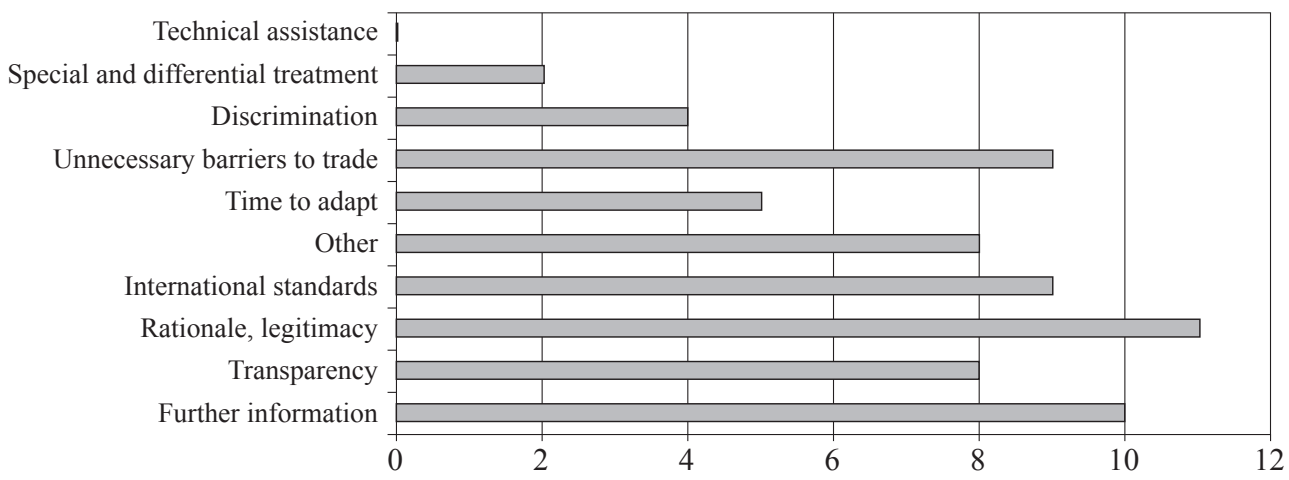

* From 15 October 2012 to 15 May 2013 (covering November 2012 and March 2013 TBT meetings).

Source: WTO Secretariat, WT/TPR/OV/W/7 5 July 2013 (13-3559), Page: 1/72, Trade Policy Review Body, Report to the TPRB from the Director-General on Trade-Related Development (Mid-October 2012 to mid-May 2013).

From 1995 to May 15, 2013, members raised 376 STCs in the TBT Committee, and so the number of STCs raised and discussed in the Committee has grown over the last five years (Chart 2). Although in 2012 members raised fewer new STCs as compared to 2011, the total number of STCs discussed in the TBT Committee continue to display an upward trend (WT/TPR/OV/W/7, 2013).

\section{Chart 2. Number of TBT specific trade concerns raised per year}

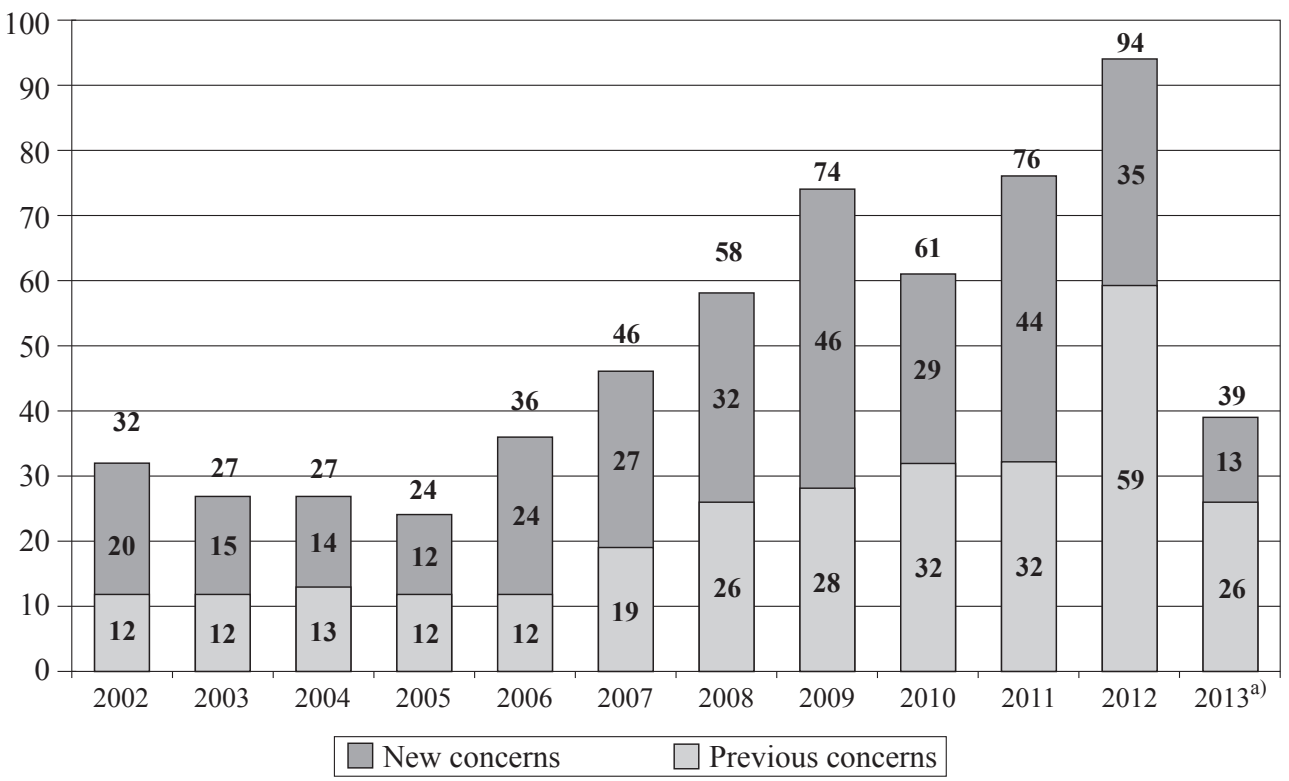

a) Data for 2013 includes only those STCs ralsed at the TBT Committee meeting of the year (held in March 2013).

Source: WTO Secretariat, WT/TPR/OV/W/7 5 July 2013 (13-3559), Page: 1/72, Trade Policy Review Body, Report to the TPRB from the Director-General on Trade-Related Development (Mid-October 2012 to mid-May 2013). 
In the period from October 2012 through March 2013, 613 sanitary and phytosanitary measures (SPS) notifications (regular and emergency) were submitted to the WTO. Notifications from Developing-country Members accounted for $66 \%$ of the total number. In the previous six-month period, the total number of notifications was higher and the proportion of measures notified by Developing-country Members lower: from April through September 2012, a total of 696 notifications (regular and emergency) were submitted, of which 54\% were by Developing-country Members.

The number of notifications of emergency measures also dropped compared with the previous period (Chart 3). The share of emergency notifications submitted by Developing-country Members was broadly similar to that of the previous period. From October 2012 through March 2013, 79\% of the 39 notifications of emergency measures were submitted by Developing-country Members. For the previous period (April-September 2012), $81 \%$ of the 58 emergency notifications were submitted by Developing-country Members. This high proportion of emergency measures notified by Developing-country Members might stem from the fact that they do not have extensive SPS regulatory systems like Developed-country Members do, and consequently, when facing emergency challenges, they are more likely to have to introduce new regulations or change existing ones (WT/TPR/OV/W/7, 2013).

\section{Chart 3. Number of SPS notification}

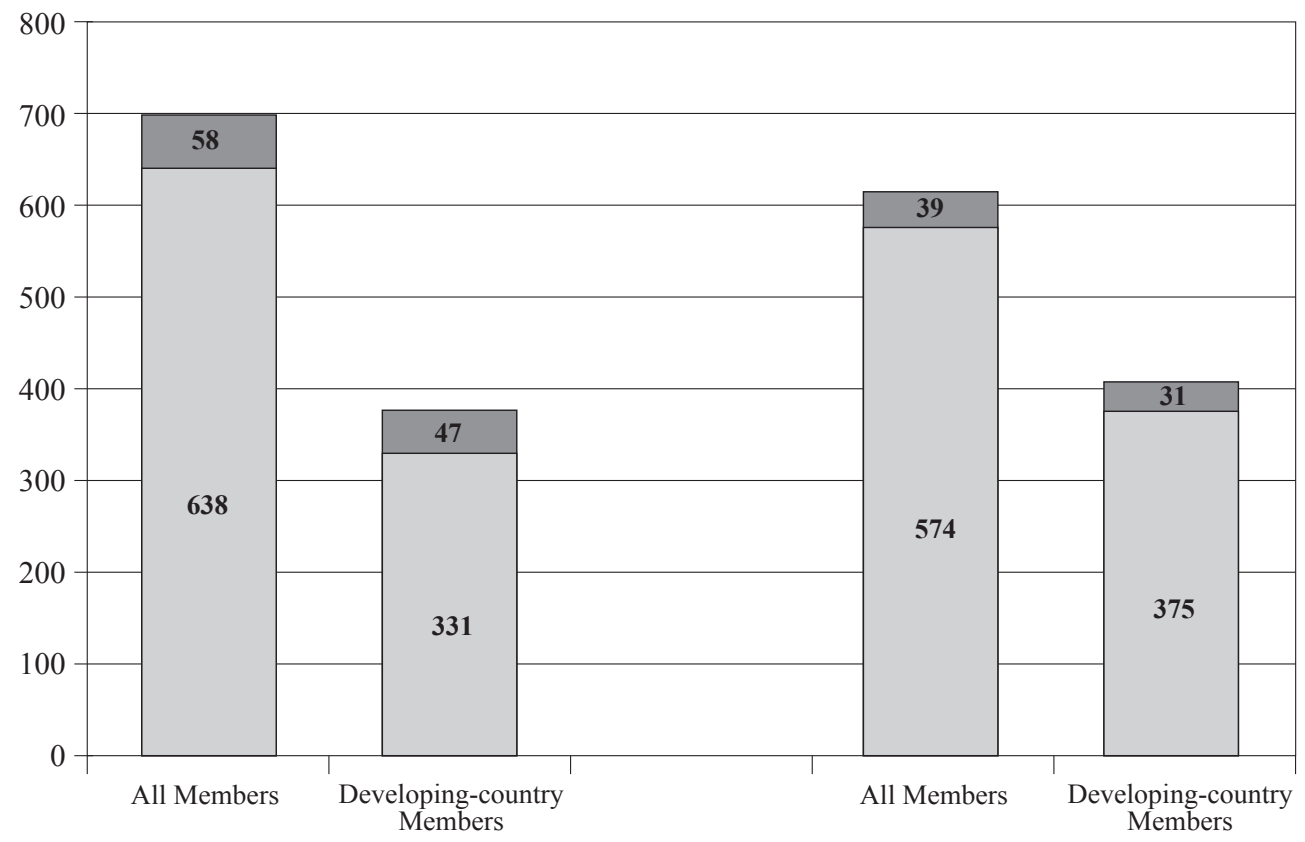

04/2012-09/2012

$10 / 2012-03 / 2013$

Regular notifications Emergency notifications

Source: WTO Secretariat, WT/TPR/OV/W/7 5 July 2013 (13-3559), Page: 1/72, Trade Policy Review Body, Report to the TPRB from the Director-General on Trade-Related Development (Mid-October 2012 to midMay 2013). 
Many members are following the recommendation to notify SPS measures even when these are based on a relevant international standard, as this substantially increases transparency regarding SPS measures. Of the 409 regular notifications (excluding addenda) submitted from October 2012 to March 2013, 215 (53\% of the total) indicated that an international standard, guideline or recommendation was applicable to the notified measure (Chart 4). Of these, $80 \%$ indicated that the proposed measure was in conformity with the existing international standard.

\section{Chart 4. Regular SPS notification and international standards}

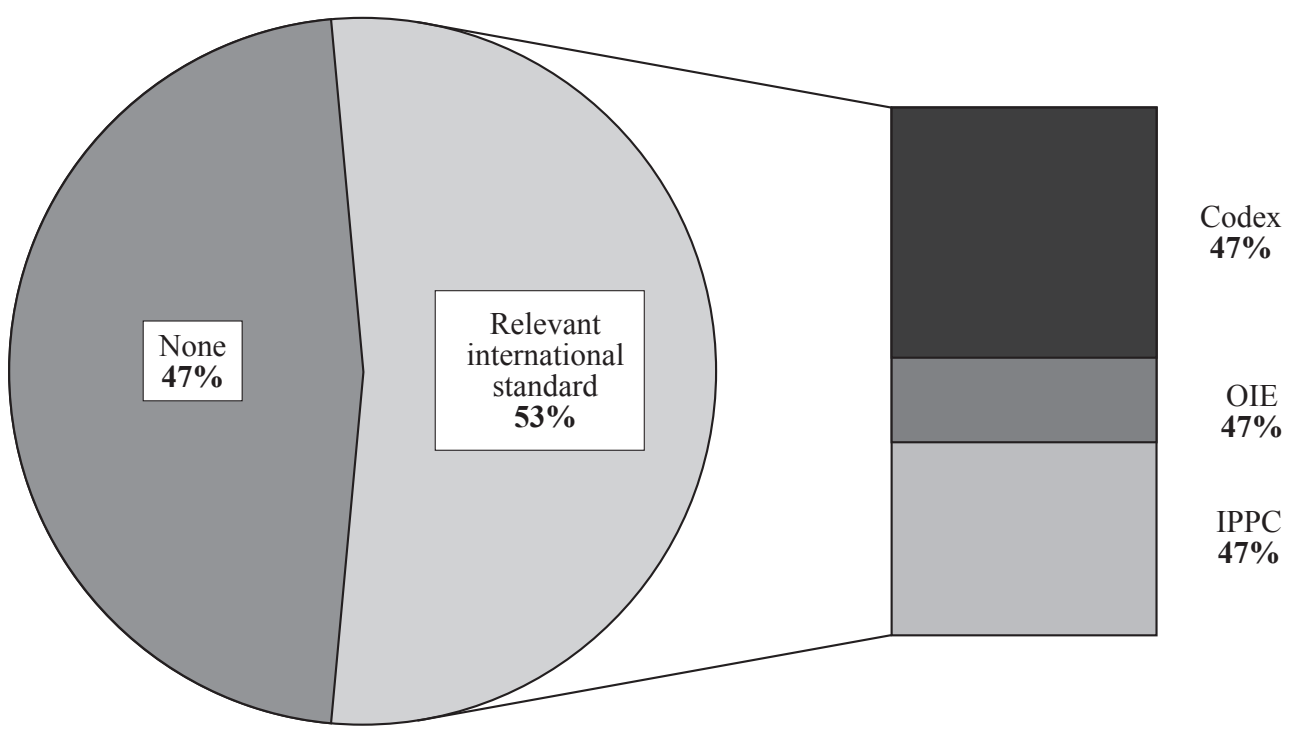

Source: WTO Secretariat, WT/TPR/OV/W/7 5 July 2013 (13-3559), Page: 1/72, Trade Policy Review Body, Report to the TPRB from the Director-General on Trade-Related Development (Mid-October 2012 to midMay 2013).

International standards often provide useful guidance regarding measures to address outbreaks of disease, or other emergency situations. Indeed, $83 \%$ of the 30 emergency notifications (excluding addenda) submitted from October 2012 to March 2013 indicated that an international standard, guideline or recommendation was applicable to the notified measure (Chart 4). Of these, 96\% indicated that the measure was in conformity with the existing international standard. Of the 574 regular notifications submitted from October 2012 to March 2013, the majority were related to food safety and the protection of humans from animal diseases or plant pests (WT/TPR/OV/W/7, 2013). The objective of an SPS measure falls under one or more of the following categories: (1) food safety, (2) animal health, (3) plant protection, (4) protecting humans from animal/plant pest or disease, and (5) protecting territory from other damage by pests. Members are required to identify the purpose of the measure in their notifications. It is not uncommon for more than one objective to be identified for a measure. The remaining notifications related to plant protection, animal health and to the protection of a member's territory from other damage by pests. Several of the regular notifications identified more than one objective per measure. 
It must be emphasized that of the 39 emergency measures notified in the same period, the majority related to animal health, followed by measures related to plant protection, the protection of humans from animal diseases or plant pests, food safety, and protection of a member's territory from other damage by pests. Similarly, the majority of emergency notifications during this period identified more than one objective per measure (Chart 5).

\section{Chart 5. Emergency SPS notification and international standards}

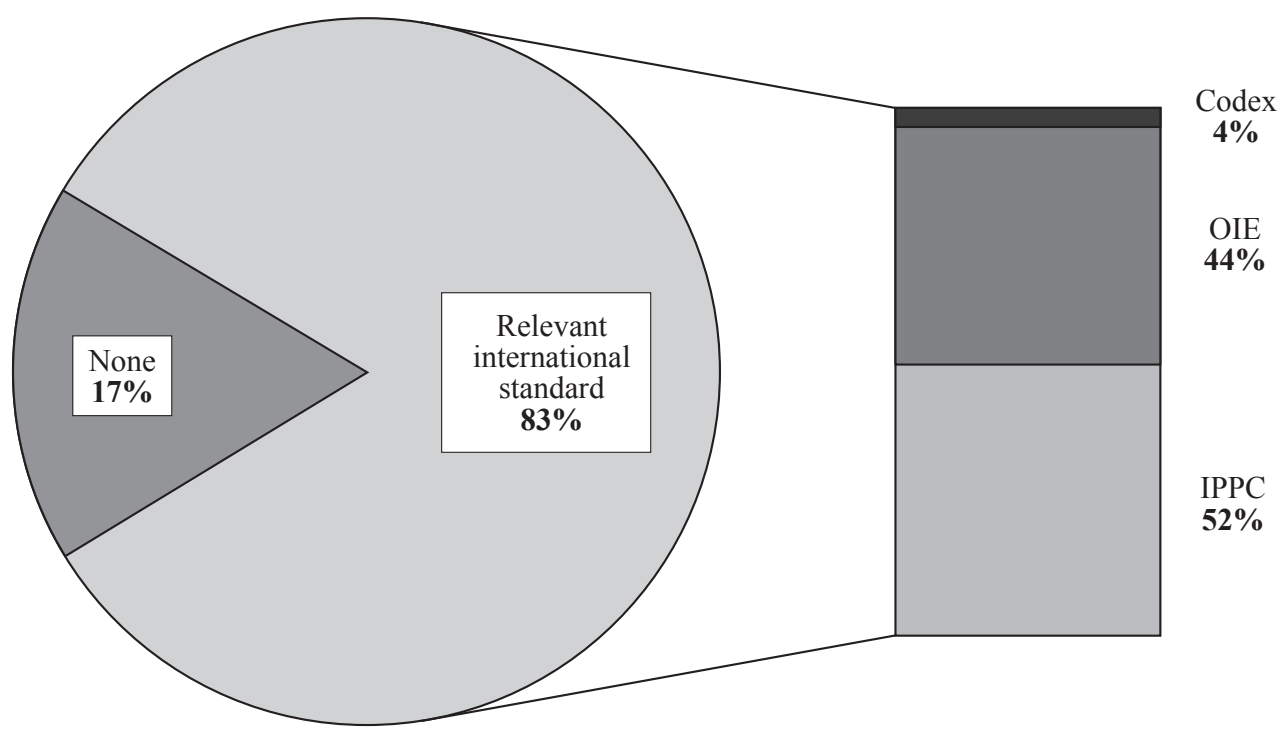

Source: WTO Secretariat, WT/TPR/OV/W/7 5 July 2013 (13-3559), Page: 1/72, Trade Policy Review Body, Report to the TPRB from the Director-General on Trade-Related Development (Mid-October 2012 to midMay 2013).

While there is no formal provision for 'counter notification,' concerns regarding failure to notify about an SPS measure, or regarding a notified measure, can be raised as a specific trade concern (STCs) at any of the three regular meetings of the SPS Committee each year. In the two Committee meetings of October 2012 and March 2013, 14 new trade concerns were raised. Four of these STCs related to food safety, six to animal health, three to plant health, and one to other concerns.

The goal of trade agreements should be to put limits on protectionist policies, without impeding governments from fulfilling their responsibilities. There is an extensive jurisprudence at the WTO that applies and elaborates the rules with this balance in mind. Upsetting the current balance could be problematic. Sensitive issues such as the EU's treatment of genetically modified foods and hormone treated meat are difficult and have not been fully resolved at the WTO (Proposed Agenda, WT/DSB/W/513, 23 September, 2013), and suggestions that new TTIP rules will help should be viewed with some skepticism.

In the negotiations for TPP, there was an effort to expand the US regulatory model to other trading partners. Whether regulatory effectiveness can be achieved anywhere is unclear; even domestic reforms along these lines are quite difficult. But trying to reconcile 
differences between two mature regulatory models like the US and EU will be a particular challenge. Both sides have spent decades developing their regulatory processes, and convergence will not be easy.

Finally, the report talks about regulatory differences (Final Report..., 2013). Regulatory differences (or 'divergence') exist when government agencies in different countries have varying regulatory requirements or processes in the same policy area. Such differences result in higher costs for businesses in a number of ways. First, companies have to comply with multiple certification and testing requirements or approval processes in order to get a product approved for sale, which takes time and money. And second, the different regulations may result in a costly need for additional production processes in order for the product to meet the different standards of each market (Lester, Barbee, 2013).

It must be emphasized that regulatory divergence across countries can arise for a number of reasons. For one thing, policy objectives may vary. If countries are trying to achieve different goals, their regulations are unlikely to correspond. But even where policy objectives are similar, regulating through an isolated process, in which national agencies make decisions without thinking about what their foreign counterparts are doing, can lead to differences in regulation (Lester, Barbee, 2013).

The impact varies depending on the nature of the divergence. It may be that, due to different regulatory requirements, two markets end up somewhat isolated, with products made in each essentially restricted to the domestic market. Alternatively, one market might have regulations that are more flexible, and thus products are excluded only from the market with stricter regulations (Lester, Barbee, 2013). There is a separate approval process in each market, which means that while products can be sold in both markets, there is an added cost from going through multiple regulatory reviews.

\section{The nature and the promoters of the Transatlantic Trade and Investment Partnership (TTIP)}

Examining the nature of the US-EU trading relationship, it is not hard to see why regulatory issues are of such high importance. A large portion of US trade with the EU is intra-industry and intra-firm, which means TTIP is likely to bring about changes within existing value chains, rather than relocation of whole industries. The major barriers to trade and investment, then, go beyond tariffs, and also include bureaucratic red-tape caused by incompatible rules and regulations that impede and slow down the free movement of goods and services (Lester, Barbee, 2013).

It is very important to understand the nature of the projected gains. The magnitude and range of the total impact of TTIP on GDP were taken from Felbermayr et al. (2013a), who give estimates for the United States, the 27 countries of the European Union, and 98 countries of the rest of the world. With their macro general equilibrium model, Felbermayr et al. (2013a) consider two scenarios. A "low impact" scenario calculates only the direct effect of reducing trade costs by eliminating existing tariffs in all sectors. The "high impact" scenario adds the removal of non-tariff barriers and projects the impact of the increase in trade activity on investments and economic growth (Buongiorno et al., 2014). 
The promoters of the TTIP have tried to sell the agreement to the public on both sides of the Atlantic as a way to boost growth and create jobs. At a time when both the US and European economies are still suffering from the effects of recession, anything that boosts growth sounds appealing. However, a closer look at the projections indicates that the promised growth is not likely to amount to much. Furthermore, there will likely be negative aspects to any deal that could far outweigh any gains.

For the purpose of the present study, the projections by Felbermayr et al. (2013a) of the cumulative change in GDP with the low or high scenario were converted into annual growth rates over a decade, the time needed for almost full impact (Felbermayr, 2013b). It was further assumed that the effect of TTIP on GDP would begin in 2015 and end in 2025 , but the simulations continued until 2030 to absorb any residual dynamic effect on the forestry sector (Buongiorno et al., 2014).

The Centre for Economic Policy Research in the United Kingdom also uses a standard economic model to project the fully realized impact of TTIP by 2027. In what it considers the most likely scenario for a final deal, its model projects that TTIP would increase the GDPs of the EU and the US by 0.5 and 0.4 percentage points respectively. While more growth is generally better than less growth, the projected gains for the EU come to less than 0.04 percentage points annually. For the United States, the projected gains are 0.03 percentage points a year. Thus, the growth increases will be far too small to notice in the annual GDP data (Lester, Barbee, 2013).

Moreover, this growth does not imply additional job growth, as the Centre made clear in its summary. TTIP is assumed to increase the efficiency with which a particular supply of labor is used; it does not increase the demand for labor. In fact, the summary explicitly notes the agreement could lead to job losses in the short run, as lower cost imports displace some workers.

Furthermore, the projections only consider ways in which the agreement may speed growth by reducing barriers. There are also likely to be provisions that slow growth by increasing barriers, most notably in the area of patent protection, especially for prescription drugs.

If the deal strengthens patent or related protections for drugs, then it will lead to higher drug prices. This will drain money out of the economy and lead to more inefficiency, in the same way that higher tariffs on imports lead to higher prices and inefficiency. The difference is that tariffs are rarely more than twenty or thirty percent in advanced economies, where as patent protection can raise the price of drugs by several thousand percent above their free market price (Lester, Barbee, 2013).

There are other elements of TTIP that should raise concerns on both sides of the Atlantic. Since formal trade barriers between the EU and the US are already low, the negotiations are mostly focused on non-trade issues. This will involve areas of regulation that are currently under the control of national or subnational governments. For example, TTIP could include provisions on how genetically modified foods are regulated. TTIP provisions could make restrictions on the sale or planting of GMO crops an unfair trade practice. They could also limit the ability of governments to impose labeling requirements.

TTIP could also include provisions on fracking, the process of drilling for deep deposits of natural gas or oil. Federal legislation in the United States has exempted companies engaged in fracking from complying with decades-old environmental restrictions 
that were designed to ensure the safety of drinking water. As a result, there have been numerous complaints that fracking operations have resulted in the contamination of drinking water near fracking sites. However, these allegations are difficult to assess, because the oil and gas companies are not required to disclose the chemicals they use in the fracking process.

There are many other areas where regulations that would not be approved by national or subnational governments may effectively be imposed through TTIP. This is in fact one of the main motivations of TTIP: it provides a channel around the democratic process in both the EU and the US. Regulatory changes that may not be possible to achieve due to domestic political considerations may be imposed on a country through a trade agreement which will be presented to the elected legislatures on both sides of the Atlantic as an all or nothing proposition.

This is perhaps clearest in the case of investor-state dispute settlement (ISDS). This is a process that the United States has established as part of numerous trade deals over the last three decades. It involves the creation of special panels outside the control of the government in question to decide issues related to disputes with foreign investors. For example, if a US company felt that a regulation imposed by the Mexican government was unfairly imposing costs on it, the company could take its complaint to a special panel established for this purpose, rather than going through Mexico's legal system.

This might make sense in certain situations, and may even be mutually beneficial in countries that lack a well-functioning legal system. Foreign companies may be reluctant to invest in a developing country if they are concerned that they would not be able to get adequate redress through that country's legal system. By setting up an alternative mechanism, potential foreign investors can be more confident that laws will be fairly applied. Independent panels that are beyond government control give investors more protection than a promise from the government. Even if the government is sincere in such a promise, a new government may not feel bound by a prior government's commitment.

Thus, ISDS may in fact make sense for developing countries as a way to promote foreign investment. However, it is much more difficult to see the merits of this argument for TTIP, in which all of the countries involved have long-established legal traditions and many decades of experience with independent judiciaries. It is difficult to believe that courts in Denmark, Germany or the United States could not be trusted to treat foreign investors fairly.

On the other hand, it is reasonable for citizens of the EU and US to question whether the new legal system being set up under TTIP can be counted on to respect the rights and interests of anyone other than foreign investors. This does not mean that ISDS will necessarily have a pro-investor bias, but if there is no obvious anti-investor bias in the current legal system, then why is it necessary to establish a new dispute settlement mechanism?

In short, TTIP is much more than a free trade agreement designed to reduce tariffs and quotas. It would create a structure of regulation and a new legal system that would remove authority in a wide variety of areas from democratically elected bodies and the existing legal structure. TTIP could be both a symbolic and practical assertion of Western renewal, vigor and commitment, not only to each other but to high rules-based standards and core principles of international order. It can be assertive, yet need not be aggressive. It challenges fashionable notions about a "weakened West" (Hamilton, 2014). 
TTIP's goal is to eliminate all impediments in bilateral trade in goods and investments according to the principle of origin. For the trade in services, the aim is to obtain improved market access and to address the operation of any designated monopolies and state-owned enterprises (Straubhaar, 2014).

Since the projected economic gains from this deal are relatively modest, there is no reason that anyone should feel an irrepressible need to grab at whatever final deal comes out of the negotiations. It would be best if any moves towards superseding the established systems be done with careful consideration, and not the rushed, all-or-nothing approach envisioned by the governments negotiating TTIP. If the TTIP timeline does not allow for thorough debate, it can always come back to the issue of reducing trade barriers later.

\section{Interrelationship between regulatory standards and international cooperation in TTIP}

In theory, problems of regulatory divergence can be solved without international cooperation. Just like with free trade in general, governments could liberalize unilaterally. In the context of regulations, governments could simply declare that products complying with foreign regulations in the same area will be deemed acceptable for import. US regulators could accept EU headlights; and EU regulators could accept US GM foods. However, in practice, domestic political resistance, sometimes for protectionist purposes, often means that solutions to these problems will require international cooperation. Government regulators from different countries need to sit down and hash out the issues (Lester, Barbee, 2013).

How should international cooperation work in practice? There are two common methods - both of which are referred to in the HLWG report (Final Report..., 2013) - which have been used to deal with regulatory divergence: harmonization and mutual recognition (Lester, Barbee, 2013).

Harmonization implies the alignment of regulations to a single best practice. Usually a voluntary agreement, harmonization can be based on a reference to international standards from a standard-setting body, or simply involve coordination among nations. Countries basically agree to converge on a single standard or regulation. This is usually the most difficult way to achieve regulatory cooperation, in part because countries are reluctant to adjust their standards, and also because the harmonization of standards requires complete consensus (Lester, Barbee, 2013).

Mutual recognition can be achieved through agreements or the acknowledgement of regulatory equivalence. Mutual recognition agreements approve the testing and certification processes of other countries as acceptable for allowing sale in their own country. This method is especially useful in eliminating duplicative testing and certification processes. Recently, this approach was employed in a mutual recognition agreement between the US and Israel in relation to telecommunications equipment: Israeli regulatory authorities will accept tests that recognized US laboratories perform to determine the conformity of telecommunications equipment with Israeli technical requirements, rather than requiring additional testing by Israeli laboratories, in order for American products to be sold in Israel (USTR Press Release, 2012). 
Efforts to deal with regulatory barriers at the GATT/WTO eventually resulted in the TBT Agreement, which reinforces traditional GATT rules on nondiscrimination, and also goes a bit further to deal with the trade effects of burdensome regulation. Current efforts in the TBT Committee involve work on good regulatory practices, including developing a list of voluntary principles and mechanisms that represent best practices in developing and applying regulations (WTO News Item, 2013).

Cooperation could occur organically, of course, outside the context of an international agreement. Regulators from different countries could simply sit down with each other and coordinate their diverging regulations. But this does not happen often in practice, and has not occurred between the US and the European Union, and there is little reason to think it will any time soon. As a result, a formal mechanism to push this process along would be of great value. The private sector needs a better way to point out the problems it is experiencing, and regulators must be given an opportunity to cooperate with their counterparts in other countries. The question then becomes: what should this mechanism look like? One approach that has been put forward would focus on requiring domestic regulators to look at what their colleagues abroad are doing (Lester, Barbee, 2013).

This approach emphasizes the role of regulators themselves and their decision-making processes. While there might be some value to this, it also has the potential to be more burdensome than helpful. If every regulation that has an impact on trade - i.e. virtually all regulations - requires consideration of how the other side regulates the same issue, the role of bureaucracy in dealing with these issues could actually increase, and as a result this approach may actually raise more problems than it solves.

Instead of turning first to the regulators, a better approach to regulatory cooperation would be to focus attention on the views of the private sector, which faces the responsibility of meeting multiple government requirements, and which is in the best position to identify the costs and inefficiencies of regulatory divergences in trade. If business and consumer groups are not even concerned about a particular area of regulation, burdening the regulators with extra work is unnecessary. Thus, one of the main goals of the regulatory cooperation process should be to facilitate the involvement of producers, distributors and consumers in a process which provides for direct contact with the relevant government agencies. This further assists in identifying the priority sectors that need the most immediate attention and would yield the greatest economic benefit if divergences are narrowed (Lester, Barbee, 2013).

Private sector involvement could take place at two stages. First, during the initial rule-making process for new regulations, there could be requests for input on potential conflicts with other countries' regulations. This would be helpful in preventing new regulations from diverging in the first place. Second, with regard to existing regulations, it is essential to have private sector input on how divergent rules hamper trade so that discussion can even begin. Since regulatory convergence will be a long-term process, there needs to be a permanent forum where the private sector - businesses, consumers and other groups - can raise concerns with both existing and potential divergence (Lester, Barbee, 2013).

While TTIP offers a good starting point, regulatory cooperation should eventually be done on a multilateral basis. The need for this is amplified by the growing trend of 
$21^{\text {st }}$ century trade agreements that include issues outside the traditional scope of trade negotiations. Outgoing WTO Director-General Pascal Lamy has articulated this problem clearly, suggesting that "while bilateral tariff reductions can ultimately be multilateralized, a plethora of bilateral trade agreements will produce a multitude of regulatory standards with which businesses will struggle to comply" (Lamy, 2013). This simply means that if regulatory cooperation is included in multiple trade agreements with different participants, the risk of creating more layers of contradiction and confusion greatly increases. For instance, how different will the regulatory cooperation chapter of TPP be from TTIP? Would it not be better to open up the discussion of regulatory burdens on trade to a wider group of countries to maximize the area in which inefficiencies can be eliminated (Lester, Barbee, 2013)?

Without getting into too much detail here, multilateral regulatory cooperation could be undertaken through an international forum of some sort. It need not be based on an enforceable treaty. A more flexible structure, based on the idea of agreed cooperation, may be preferable. The goal is not to push countries to take on difficult and sensitive legal obligations; rather, it is to seek out regulatory issues where countries can voluntarily work together (Lester, Barbee, 2013).

Multilateralizing regulatory cooperation may not be possible at this moment, but there is still a great deal of value to be had from US-EU cooperation. Since the US and EU make up almost half of global GDP and 30\% of total goods and services trade (Final Report..., 2013), any agreement both sides can come to on regulatory issues could help set the tone and trajectory of future regulatory cooperation efforts involving other parties. The greater the number of countries involved in eliminating costly and duplicative regulatory processes, the greater the potential gains for consumers and producers alike. The TTIP negotiations can play an important role in leading the way on regulatory cooperation efforts, and their success or failure will determine how this issue is addressed in the future (Lester, Barbee, 2013). It is important to underline that, in this new situation for the cooperation between the EU and US, large foreign partners of the US and EU also have a significant position.

All studies foresee a small impact of removing trade barriers alone, and a larger impact of eliminating non-tariff barriers. Some disagree on the potential impact on third countries. While the OECD (2005) suggests that reducing barriers to trade between the EU and the US will have mostly positive spillover effects on third party countries such as Canada, Mexico, Turkey, Japan and China, Felbermayr et al. (2013a) estimate that third party countries will lose market share in the US and the EU due to the increased trade between the two regions, and that this will have a negative effect on their economies. Additionally, Felbermayr et al. (2013a) foresee a decrease in trade within EU countries, for example a 23\% decrease in trade between France and Germany (Buongiorno et al., 2014).

Most national and international studies on the macroeconomic impact of transatlantic trade agreements are based on general equilibrium approaches, such as the Global Trade Analysis Project (GTAP) model (Berden et al., 2009; Francois et al., 2013; OECD, 2005). This can combine the GTAP database with trade gravity models (Egger, Pfaffermayr, 2011) into a general equilibrium model to project the macroeconomic impacts of TTIP in the US, the EU, and third countries. 
It is interesting to explore the effect of proliferating deep regional agreements on coherence in international trade governance (Jackson, 2013). The WTO suggested that new international trade rules be negotiated and decided outside the WTO, where power differences are greater and where the principles of non-discrimination and reciprocity are absent. It also argued that TTIP is here to stay. Governments will need to ensure that regional agreements and the multilateral trading system are complementary, and that multilateral disciplines minimize any negative effects from PTAs (Krist, 2013). While the available literature suggests that deep integration rules are often non-discriminatory - for instance, provisions in the services or competition policy areas are often extended to non-members - certain provisions in regional agreements can contain discriminatory aspects that clash with the multilateral trading system. It has been shown that PTAs which make it more difficult to apply contingency measures to PTA partners may divert protectionist measures towards non-members (Prusa, Teh, 2010).

Deep provisions can also have a number of adverse systemic effects. For example, the important effects of regional regulatory harmonization can make it more difficult to multilateralize rules. PTAs may not include third-party most-favored nation (MFN) clauses, thus effectively discriminating against other countries. Developed country exporters may view bilateral and regional, rather than multilateral agreements, as faster and easier routes for achieving their objectives, further weakening the principle of nondiscrimination.

With regard to services supply chains, some argue that their growth creates an additional need to re-examine and modernize current rules for services trade as these rules were designed for a world where services were exported as final products from national firms, not a world where multiple firms supply stages of services production from multiple locations. Recent research on how differences in firms have an impact on trade policies reveals a related concern. Ciuriak et al. (2011) point at another difference between deep integration at the regional and at the multilateral level (Ciuriak et al., 2011). While heterogeneous firms' trade models suggest that more importance should be granted to extensive than to intensive margin responses to trade opening, there is evidence suggesting that PTAs have positive effects at the intensive margin and negative effects at the extensive margin, whereas the opposite is true of openings in the multilateral context.

\section{Results and Findings}

Transatlantic reforms could set a powerful precedent for initiatives like TTIP in other regions and in the World Trade Organization (WTO). Contrary to concerns that another broad-based bilateral accord would further dampen prospects for an international trade agreement, it is believed that a properly constructed TTIP could help break the deadlock in the WTO's Doha Round negotiations. In particular, TTIP provisions could become a template for the stalled global trade talks in several difficult areas, from agriculture to crossborder rules on services, investment and regulations. A comprehensive TTIP has important implications for both bilateral trade and the world trading system. If successful, it could strengthen transatlantic economic relations, while also spurring trade reforms that both sides could jointly put forward to reinvigorate flagging multilateral trade negotiations. 
Ideally, the best way to address problems arising from regulatory divergence would be on a multilateral basis. In advance of that eventual goal, however, a US-EU regulatory cooperation process could lay the foundations for a broader effort in the future. If the US and the EU can resolve some of the easier issues - like mundane problems such as different regulations for automobile headlights - perhaps that can serve as a building block for a broader multilateral effort. Success in this area will be difficult, but the gains are potentially large, and thus an attempt to solve this long-standing problem is worth the effort.

Negotiations for TPP and TTIP could be vehicles for establishing a WTO Plus system. These agreements establish effective rules regarding neomercantilist practices and eschew special interest provisions. Such a WTO Plus system would both open markets for countries willing to accept strengthened trade rules and put pressure on nonparticipating countries to further open their markets and adopt similar rules in a future multilateral trade round within the framework of the WTO.

It must be emphasized that in the new WTO, its diverse membership must find common ground on new areas of negotiation. The process of these negotiations must begin with domestic adjustment and development trade policies, and continue by harnessing all the available incentives, from TTIP to aid-for-trade, and by new forms of cooperation between developed, developing, and emerging countries. The economic incentives for multilateral trade liberalization remain strong, and the new international economy of more broadly shared economic power represents a major victory for its success in the framework of the WTO multilateral trade system, but power in the WTO has a symbolic character.

The US and the EU must deepen their ties to each other, must keep their eyes on the prize and work with emerging powers, democracies and non-democracies alike, to fashion a new rules-based system for the $21^{\text {st }}$ century. The challenge ahead is helping to extend that accomplishment to the rest of the world. The TTIP initiative comes at the right time. Now the benefits of doing business with emerging markets have declined and transaction costs have increased. The financial crisis has led to high unemployment rates and high public debts on both sides of the Atlantic. New impulses for growth are needed to improve prospects for employment, growth and welfare.

TTIP could spur growth, translate into millions of new jobs in the United States and Europe, and improve both earnings and competitiveness for many companies, particularly small and medium-sized enterprises on both sides of the Atlantic. However, the benefits would not be only to the United States and the EU. They would spread out worldwide. TTIP is open and encourages third countries to join. As a result, TTIP would become the core of a new global trading system where the most advanced economies are the rule-setters once again. In the long run, all countries could benefit from more prosperity in the transatlantic area. That is why TTIP needs to be a success, not a failure.

\section{Conclusion}

The need for companies to organize their supply chains across different countries has led to a demand for regional agreements like TTIP that cover more than preferential tariffs. The harmonization of standards and rules on investment, intellectual property and 
services has become a standard part of new trade agreements. The differences among firms involved in trade are also important for future development. The picture that arises from trade is that even if many companies are indirectly involved in trade-related activities, relatively few are exporting or importing and these companies tend to be larger and more productive than others. Such companies also have a role in technology advancement and the diffusion of know-how through supply chains.

Trade policy plays a key role in the maintenance of both economic and political liberalization. The prominence of profit seeking in a country can have far-reaching implications for its economic development. Especially in transitional countries, profit seeking takes scarce resources out of productive areas in the economy, using them to promote and perpetuate further profits. The United States and the EU are each other's most important trade partners. Both regions have similar cost and production structures, similar levels in economic development, deep political relations and strong cultural similarities. Therefore the reduction of trade frictions could help to reallocate production factors more efficiently, especially capital firms and their production sites, and to make use of comparative advantages, economies of scale and joint research activities to develop new technologies. However, it should be stressed that free trade in itself is not responsible for economic growth, but that macroeconomic stability and increasing investment are more significant.

If TTIP succeeds, the partners will make an effort to conform to all these agreements in trade coverage and rules of origin, in particular to reduce distortions and generalize the benefits. A TTIP, complementing NATO and the other longstanding political and alliance links between the US and EU, will form the foundation for a strengthened "Atlantic Basin" that can confidently turn to the Pacific, the Middle East or other challenges in the decades ahead. That will be the strategic significance of TTIP. It needs to be emphasized that no other two groups of nations have closer ongoing collaboration on security, intelligence and political matters than the NATO partners of Europe and North America. The United States and Europe are able to take decisive steps forward at a time when solidarity between them is greatly needed to revitalize their own economies, to reinforce their cooperation and to play a collective leadership role in promoting their values on the global world.

\section{Bibliography}

Agreement on Technical Barriers to Trade (1994), 15 April 1994, WTO Agreement, Annex 1A, Results of the Uruguay Round of Multilateral Trade Negotiations: The Legal Texts, p. 138.

Agreement on the Application of Sanitary and Phytosanitary Measures, 15 April 1994, WTO Agreement, Annex 1A, Results of the Uruguay Round of Multilateral Trade Negotiations: The Legal Texts, p. 69.

Berden K. G., Francois J., Thelle M., Wymenga P., Tamminen S., (2009), Non-tariff measures in EUUS trade and investment - an economic analysis, ECORYS Nederland BV, Rotterdam.

Buongiorno J., Rougieux P., Barkaoui A., Zhu S., Harou P. (2014), Potential impact of a Transatlantic Trade and Investment Partnership on the global forest sector, Department of Forest Economics, Swedish University of Agricultural Sciences, Umeå, Published by Elsevier GmbH, "Journal of Forest Economics", 20, pp. 252-266. 
Ciuriak D., Lapham B., Wolfe R., Collins-Williams T., Curtis J. M. (2011), Firms in International Trade: Towards a New Trade Policy, November.

Department of Commerce, U.S.-Mexico High Level Regulatory Cooperation Council, http://trade.gov/ hlrcc/, 15 November 2013.

Egan M. (2003), Constructing a European Market, Oxford University Press, New York, p. 256.

Egger P., Pfaffermayr M. (2011), Structural estimation of gravity models with path-dependent market entry, CEPR Discussion Paper No. DP8458, http://www.ssrn.com/abstract=1889961.

Felbermayr G., Heid B., Lehwald S. (2013a), Transatlantic Trade and Investment Partnership (TTIP) who benefits from a free trade deal?, Part 1: Macroeconomic effects, http://issuu.com/bertelsmannfoundation/docs/ttip-ged, study 17 June 2013.

Felbermayr G., Larch M., Flach L., Yalcin E., Benz S. (2013b), Dimensionen und Auswirkungen eines Freihandelsabkommens zwischen der EU und den USA, Studie im Auftrag des Bundesministeriums für Wirtschaft und Technologie, München, http://www.cesifo-group.de/portal/page/ portal/DocBaseService/studien/ifo_AH_2013_TAFTA_Endbericht.pdf.

Federal Register, vol. 77, no. 227, 26 November, 2012, at 70538.

Final Report, High Level Working Group on Jobs and Growth (11 February 2013), http://www.ustr. gov/.

Francois J., Manchin M., Norberg H., Pindyuk O., Tomberger P. (2013), Reducing transatlantic barriers to trade and investment - an economic assessment, Center For Economic Policy Research, London, http://trade.ec.europa.eu/doclib/docs/2013/march/tradoc 150737.pdf.

Hamilton D. S. (2014), TTIP's Geostrategic Implications, in: The Geopolitics of TTIP Repositioning the Transatlantic Relationship of Changing World, ed. D. S. Hamilton, Centre for Transatlantic Relations, Paul H. Nitze School of Advanced International Studies, John Hopkins University, Washington DC.

HLWG (2013), Final report of the high level working group on jobs and growth, http://trade.ec.europa. $\mathrm{eu} /$ doclib/docs/2013/february/tradoc 150519.pdf.

Jackson R. J. (2013), Global Politics in the $21^{\text {st }}$ Century, Cambridge University Press, New York.

Krist W. (2013), Globalization and America's Trade Agreements, John Hopkins University Press, Baltimore.

Kupchan Ch. A. (2014), Parsing TTIP's Geopolitical Implications, in: The Geopolitics of TTIP Repositioning the Transatlantic Relationship for a Changing World, ed. D. S. Hamilton, Centre for Transatlantic Relations, Paul H. Nitze School of Advanced International Studies, John Hopkins University, Washington DC.

Lamy P. (2013), Putting Geopolitics Back at the Trade Table, speech at the IISS-Oberoi Discussion Forum in Delhi (29 January 2013), http://www.wto.org/english/news_e/sppl_e/sppl264_e.htm, 15 November 2013.

Lester S., Barbee I. (2013), The Challenge of Cooperation: Regulatory Trade Barriers in the Transatlantic Trade and Investment Partnership, "Journal of International Economic Law", vol. 16, Issue 4, pp. 847-867.

North American Free Trade Agreement Technical Working Group on Pesticides Five-Year Strategy 2008-2013: Maintaining Progress (2013), http://www.hc-sc.gc.ca/cps-spc/pubs/pest/_corpplan/nafta-alena-strat-plan/index-eng.php\#toc, 15 November 2013.

OECD (2005), The benefits of liberalising product markets and reducing barriers to international trade and investment: the case of the United States and the European Union, OECD economics department working paper no. 432, http://search.oecd.org/officialdocuments/displaydocumentpdf /?doclanguage $=$ en $\&$ cote $=\mathrm{ECO} / \mathrm{WKP} \% 282005 \% 2919$.

USTR Announces Agreement With European Union In Beef Hormones Dispute, http://www.ustr.gov/ about-us/press-office/press-releases/2009/may/ustr-announces-agreement-european-unionbeef-hormones-, 15 November 2013. 
Prusa T. J., Teh R. (2010), Protection Reduction and Diversion: PTAs and the Incidence of antidumping Disputes, NBER Working Papers 16276, National Bureau of Economic Research, Inc.

Regulation (EU) 126/2012 of 14 February 2012 amending Regulation (EC) No 889/2008, http://www. fas.usda.gov/organ\%20ictrade/Agreement.pdf, 15 November 2013.

Straubhaar T. (2014), TTIP's Don't Lose Momentum!, in: The Geopolitics of TTIP Repositioning the Transatlantic Relationship for a Changing World, ed. D. S. Hamilton, Centre for Transatlantic Relations, Paul H. Nitze School of Advanced International Studies, John Hopkins University, Washington DC.

Ries Ch. (2014), The Strategic Significance of TTIP, in: The Geopolitics of TTIP Repositioning the Transatlantic Relationship for a Changing World, ed. D. S. Hamilton, Centre for Transatlantic Relations, Paul H. Nitze School of Advanced International Studies, John Hopkins University, Washington DC.

The Transatlantic Trade and Investment Partnership (2013), Why Does it Matter?, OECD, 13 February 2013, http://www.oecd.org/trade/TTIP.pdf, 15 November 2013.

USTR Press Release (2012), New United States-Israel Telecommunications Agreement Eases Way for U.S. Exports', 15 October 2012, http://www.ustr.gov/about-us/press-office/press-releases/2012/ october/us-israel-telecomm-mou-eases-way-for-exports, 15 November 2013.

Watson K. W., James S. (2013), Regulatory Protectionism: A Hidden Threat to Free Trade, Policy Analysis 723, 9 April 2013, http://www.cato.org/publications/policy-analysis/regulatory-protectionism-hidden-threat-free-trade, 15 November 2013.

WTO News Item (2013), Members continue to discuss "good practices" for technical regulations, 17-20 June 2013, http://www.wto.org/english/news_e/news13_e/tbt_17jun13_e.htm, 15 November 2013.

WTO (2013), Understanding the WTO: principles of the trading system, World Trade Organization, http://www.wto.org/english/thewto e/whatis e/tif e/fact2.

WT/TPR/OV/W/7 (2013), Trade Policy Review Body, Report to the TPRB from the Director-General on Trade-Related Development (Mid-October 2012 to mid-May 2013), 5 July 2013 (13-3559), Page: $1 / 72$.

\author{
W kierunku Transatlantyckiego Partnerstwa \\ w dziedzinie Handlu i Inwestycji (TTIP) \\ między Unią Europejską a Stanami Zjednoczonymi
}

\title{
Streszczenie
}

Autor tej pracy badawczej skupił się na analizie działań zmierzających do zawarcia Transatlantyckiego Partnerstwa w dziedzinie Handlu i Inwestycji (TTIP) przez Unię Europejską i Stany Zjednoczone. Podkreślono, że negocjacje przyczynią się do ograniczenia barier regulacyjnych. Nowe porozumienia zmierzające do usunięcia barier handlowych mają na celu zmniejszenie zbędnych kosztów i zwiększenie zysków społecznych netto $z$ handlu międzynarodowego. W artykule przeanalizowano wpływ umów o wolnym handlu, takich jak TTIP, a w szczególności mechanizmów rozstrzygania sporów między inwestorem a państwem polegających na zmniejszeniu prerogatyw rządów krajowych w dziedzinach regulowania i eliminowania nierówności rynkowych. W artykule przedstawiono przykłady skutecznych działań w zakresie współpracy regulacyjnej w nadziei, że rzuci to światło na możliwe podejścia do rozwiązywania rozbieżności regulacyjnych. Najlepszym sposobem rozwiązywania problemów wynikających z rozbieżności regulacyjnych powinna być wielostronna współpraca z uwzględnieniem stosunków UE i USA z innymi krajami. Głównym celem artykułu jest prezentacja wyzwań związanych z negocjacjami TTIP. Przedmiotem zadania badawczego są w szczególności regulacyjne bariery w polityce handlu zagranicznego USA i UE, charakter TTIP i propagatorzy tego porozumienia oraz 
wzajemne powiązania między standardami regulacyjnymi a międzynarodową współpracą w ramach TTIP. Przyjęte w pracy ogólne podejście teoretyczne spotka się z zainteresowaniem ekonomistów zajmujących się kwestiami międzynarodowymi, w szczególności współpracą transatlantycką, a także politologów. Główną metodą zastosowaną w tym badaniu jest metoda badań naukowych. Zastosowano także metodę instytucjonalną, metodę porównawczą, metodę dokumentacji i metody statystyczne. Dodatkowo wykorzystano również metody prognoz dedukcyjnych i indukcyjnych.

Słowa kluczowe: TTIP, bariery regulacyjne, współpraca międzynarodowa 